\title{
Molecular control of peptide hormone and receptor expression
}

\author{
BY ROD DIMALINE \\ Physiological Laboratory, University of Liverpool, PO Box 147, Liverpool L69 3BX
}

\section{Régulation moléculaire des hormones peptidiques et expression de leurs récepteurs}

\begin{abstract}
RÉSUMÉ
En réponse à des épreuves physiologiques tels que l'alimentation, l'expression génétique cellulaire endocrine gastrique peut être rapidement régulée dans le temps de la digestion d'un seul repas. En réponse aux modifications chroniques dans l'innervation des cellules endocrines, l'expression des gènes peut subir des modifications adaptatives à long terme.

La sécrétion acide gastrique des cellules pariétales est stimulée par l'histamine, la gastrine et l'acétylcholine; ces deux dernières agissent en relargant de l'histamine de la cellule entérochromaffine (ECL). L'abondance en ARNm de gastrine est diminuée par le jeûne, et stimulée par l'alimentation. La réduction induite par le jeûne intervient dans les 12 heures; elle se produit localement par l'intermédiaire du relargage de somatostatine déclenché par l'acidité, et est bloquée si la sécrétion acide est inhibée. Une alimentation modérée élève l'ARNm de gastrine en 30 à 60 minutes, et les niveaux stables indiquent un équilibre entre les influences inhibitoires et stimulatoires.

L'ARNm codant pour la décarboxylase d'histidine (EC 4.1.1.22; HDC; enzyme qui convertit l'histidine en histamine dans la cellule d'ECL) est fortement régulée par la gastrine, et diminue lorsque les concentrations de gastrine sont réduites par le jeûne. Inversement, l'expression de l'HDC augmente lorsque les concentrations de gastrine augmentent au cours de l'inhibition de la sécrétion d'acide; cette augmentation de l'expression de l'HDC est bloquée par les antagonistes gastrine/CCK-B. La diminution de l'ARNm de HDC avec le jeûne est progressive, mais lorsque des animaux sont renourris après un jeûne, la quantité d'ARNm de HDC double dans les 30 minutes, ce qui suggère que des modifications dans l'expression des gènes de HDC pourraient réguler la fonction sécrétoire acide dans le temps de la digestion d'un seul repas. Lorsque les niveaux de gastrine sont élevés dans des conditions supra-physiologiques pendant quelques jours, l'expression d'autres protéines de cellules d'ECL impliquées dans la biosynthèse et la sécrétion de l'histamine est stimulée. Il y a une augmentation des ARNm encodant le transporteur monoamine vésiculaire VMAT2, qui peut transporter 1'histamine dans des vésicules sécrétoires, et la chromogranine A dont on pense qu'elle stabilise le contenu des granules.

Certaines cellules endocrines gastriques montrent des formes altérées d'expression des gènes en réponse aux modifications chroniques de leur innervation. Les cellules $\mathrm{D}$ contenant de la somatostatine de la muqueuse du corpus gastrique ne sont, contrairement aux cellules D antrales, virtuellement pas affectées par les modifications de l'environnement luminal gastrique. Cependant chez des rats nouveau-nés traités avec de la neurotoxine capsaicine pour créer sélectivement des lésions sur des neurones afférents de petits diamètre, la quantité d'ARNm de somatostatine du corpus est réduite de
\end{abstract}


moitié. Chez le rat, plus de $80 \%$ des neurones afférents spinaux gastriques contiennent le peptide lié aux gènes de la calcitonine (le CGRP, qui est absent des neurones gastriques intrinsèques), et les rats immunoneutralisés activement contre le CGRP ont également un ARNm de somatostatine du corpus réduit. De plus, l'injection de CGRP élève l'ARNm de somatostatine du corpus. Il est bien connu que le CGRP est important dans les mécanismes protecteurs de la muqueuse gastrique, et il semble que certains de ces effets pourraient être favorisés par la stimulation de la biosynthèse de somatostatine. Pourtant, les rats traités ave de la capsaicine ont apparemment une muqueuse gastrique normale, et il semble possible qu'il se produise une certaine forme d'adaptation. Un de ces mécanismes pourrait être la réponse des cellules D antrales à la substance P. Ainsi, dans les rats traités avec de la capsaicine, et non chez les témoins, l'expression de la somatostatine dans les cellules $\mathrm{D}$ antrales est surrégulée en réponse à la substance $\mathrm{P}$. Comme le CGRP, la substance $P$ apparaît dans les neurones afférents gastriques qui ont des lésions dues à la capsaicine; cependant elle se trouve également dans les neurones gastriques intrinsèques, qui sont épargnés, et c'est cette dernière population qui pourrait acquérir un rôle dans la régulation de la cellule $\mathrm{D}$ antrale.

Les actions des hormones peptides se font par l'intermédiaire d'une superfamille de récepteurs couplant les protéines $\mathrm{G}$ ayant sept domaines transmembranaires. La régulation de l'expression des récepteurs offre un niveau plus élaboré de régulation. Une famille de cinq récepteurs de somatostatine a été identifiée (SSTR1-5). Il est prouvé que la SSTR2 est l'intermédiaire dans l'inhibition de la sécrétion d'acide, et dans le relargage d'histamine de la cellule ECL. Trois sous-types d'ARNm de SSTR2 ont été identifiés, et ils sont exprimés de façon différente dans l'antre et dans le corpus gastrique. De plus, l'ARNm de SSTR2 est régulé par des facteurs tels que l'acidité luminale, qui régule également l'expression de la somatostatine.

The upper gastrointestinal tract provides a useful model for studying physiological changes in gene expression because it is relatively easy to manipulate the environment of the gastric lumen, by feeding, by withdrawing food or by inhibiting gastric acid secretion. The observation that gene expression in gastric endocrine cells is regulated in response to changes in the gastric lumen environment is perhaps unsurprising; what is more striking, however, is that such changes can occur over the time taken to digest a single meal and, therefore, may influence the control of digestion on a meal-to-meal basis.

The present short review focuses on two aspects of gastric endocrine cell gene expression. First, the rapid changes in gene expression that occur within a few minutes to a few hours of ingestion of food, or in response to changes in gastric lumen $\mathrm{pH}$. Second, more-slowly developing (days to weeks) adaptive changes that occur in response to chronic changes in the innervation of the stomach. The rapid changes will be discussed in the context of the physiological control of gastric acid secretion, the long-term changes are related to gastric mucosal protection. In addition, the expression and regulation of hormone receptors will be discussed with reference to somatostatin.

\section{CONTROL OF GASTRIC ACID SECRETION}

The control of gastric acid secretion is achieved through a complex interplay of stimulatory and inhibitory factors that act through endocrine, neural and local paracrine 
mechanisms. The major physiological stimulants are the antral hormone gastrin, histamine, and acetylcholine; somatostatin exerts important inhibitory influences.

The involvement of histamine in stimulating gastric acid secretion has been recognized since the early part of the century (Popielski, 1920), and its central role was firmly established with the development of histamine $\mathrm{H}-2$ receptor antagonists (Black et al. 1972) that potently inhibit acid secretion. It is also clear that gastrin, first described by Edkins (1905), has a physiologically important role. What are less certain are the relative importance, and the mechanisms of action of histamine, gastrin and acetylcholine in stimulating the parietal cell. One view, the 'permission' hypothesis (Grossman \& Konturek, 1974), is that all three agents act directly on the parietal cell. Separate receptors for them have been demonstrated on canine parietal cells (Soll et al. 1984), and the inhibitory action of $\mathrm{H}-2$ antagonists is interpreted as removal of one element of a potentiating interaction between the three stimulants. An alternative theory, the 'transmission' hypothesis (Code, 1977; Black \& Shankley, 1987), is that acetylcholine and gastrin act by releasing histamine, which then serves as the final common stimulant of the parietal cell. Support for this idea comes from pharmacological analyses of $\mathrm{H}-2$ receptor antagonist actions in vivo (Black \& Shankley, 1987) and from the finding that gastrin and muscarinic agonists release histamine from the totally isolated, vascularly perfused rat stomach, and increase activity of histidine decarboxylase ( $E C$ 4.1.1.22; HDC), the enzyme that converts histidine to histamine in the enterochromaffin-like (ECL) cell of the gastric corpus mucosa (Hakanson et al. 1974; Sandvik et al. 1987, 1988). The transmission hypothesis currently enjoys considerable support, but the two mechanisms are not mutually exclusive and the relative dominance of one or other almost certainly differs between species.

\section{The gastrin $\left(G^{-}\right)$cell}

Gastrin mRNA abundance is depressed by fasting and stimulated by feeding. Withdrawal of food from rats for up to $48 \mathrm{~h}$ causes a progressive decline in mRNA abundance that is detectable within about $12 \mathrm{~h}$ (Dimaline et al. 1991; Wu et al. 1991). The reduction in mRNA is more dependent on lumen acid than on withdrawal of food since it is prevented if fasted animals are treated with the $\mathrm{H}^{+} / \mathrm{K}^{+}$-transporting ATPase (EC 3.6.1.36) inhibitor omeprazole, to induce achlorhydria (Dimaline et al. 1991). The acid-induced depression of gastrin mRNA is mediated in large part by somatostatin (Fig. 1); in vitro studies in dog antral mucosa demonstrated that gastrin mRNA was depressed by somatostatin, and elevated by a somatostatin antiserum (Karnik et al. 1989). In fact, antral gastrin and somatostatin mRNA abundances are reciprocally related over a wide range of gastric lumen pH (Brand \& Stone, 1988; Wu et al. 1990; Dimaline et al. 1991; Sandvik et al. 1993). Gastrin mRNA is modestly elevated within 30 min of refeeding fasted rats (Wu et al. 1991); it is further elevated if fed rats are treated with omeprazole (Brand \& Stone, 1988; Wu et al. 1990; Dimaline et al. 1991; Dockray et al. 1991).

Taken as a whole, therefore, the data suggest that physiological levels of gastrin expression depend on a balance between the stimulatory effects of feeding and the inhibitory effects of lumen acid. Much of the information on regulation of gastrin mRNA abundance originates from experiments performed on rats, but it seems likely that similar mechanisms operate in man, since patients suffering from pernicious anaemia (and who are therefore achlorhydric) have reduced somatostatin mRNA and elevated gastrin mRNA (Moss et al. 1994). 


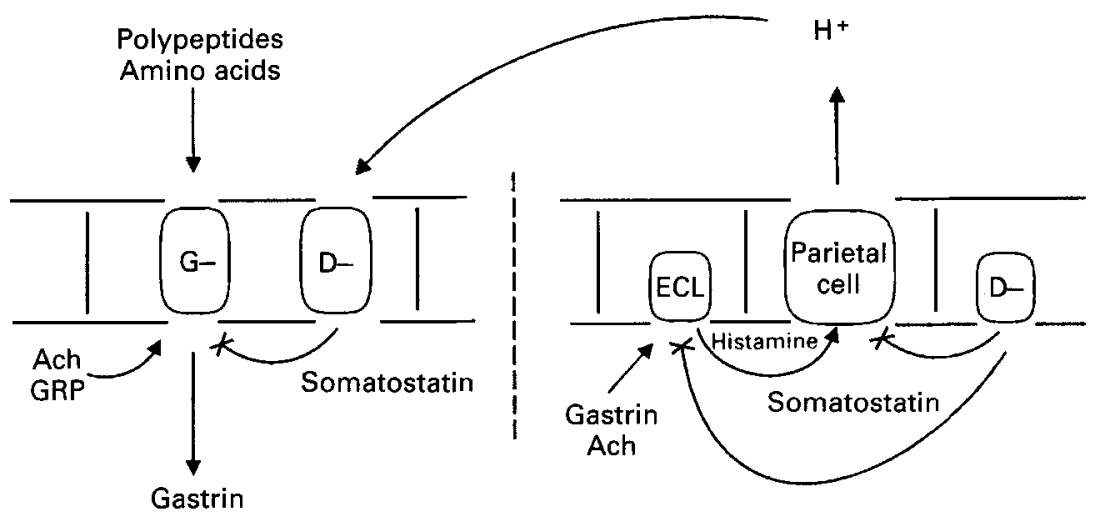

(a) Antrum

(b) Corpus

Fig. 1. Schematic representation of mechanisms regulating endocrine cell function in gastric antrum (a) and corpus (b) mucosa. ( $\rightarrow$ ), Stimulatory inputs; $(-x)$, inhibitory inputs; G-, gastrin cell; D-, somatostatin cell; ECL, enterochromaffin-like cell; Ach, acetylcholine; GRP, gastrin-releasing peptide. For further explanation, see p. $267-268$.

\section{The enterochromaffin-like cell}

Histidine decarboxylase. It is well known that HDC activity and histamine secretion are stimulated by feeding, gastric distension, gastrin and cholinergic agonists (Snyder \& Epps, 1968; Kahlson \& Rosengren, 1971; Ryberg et al. 1990; Chen et al. 1994). Gastrin, in particular, is known to have both acute and chronic effects on ECL cell function, inducing increases in both HDC activity and histamine secretion and, in the longer term, it stimulates ECL cell proliferation (Ryberg et al. 1990; Chen et al. 1994). In principle, increased histamine biosynthesis could result from de novo synthesis of HDC, or activation of a preformed inactive pool by modifications such as phosphorylation or dephosphorylation (Savany \& Cronenberger, 1990). The opportunity to examine this question arose with the identification and characterization of a complementary DNA (cDNA) from fetal rat liver, encoding the enzyme HDC (Joseph et al. 1990).

HDC mRNA abundance is regulated by changes in the gastric lumen environment. Fasting rats for up to $48 \mathrm{~h}$ progressively reduces HDC mRNA abundance to about $25 \%$ the level seen in animals fed ad lib. (Dimaline \& Sandvik, 1991; Dimaline et al. 1993b). The rat has a relatively high basal acid secretion (approximately $25 \%$ of maximal) and the HDC response to fasting may be largely due to increased gastric lumen acidity rather than withdrawal of food, since in rats fasted and treated with the proton pump inhibitor omeprazole, to induce achlorhydria, HDC mRNA was not depressed (Fig. 2; Dimaline \& Sandvik, 1991). Under normal circumstances, secretion of gastrin is inhibited by somatostatin released from antral D-cells in response to lumen acid (Fig. 1). Achlorhydria induces secondary hypergastrinaemia by dramatically reducing somatostatin biosynthesis and secretion (Brand \& Stone, 1988; Wu et al. 1990; Sandvik et al. 1993). Administration of a specific gastrin antagonist (CI988) reversed the effect of omeprazole, suggesting that in these circumstances HDC mRNA is regulated largely by gastrin (Dimaline \& Sandvik, 1991). Elevation of plasma gastrin concentrations above those seen in rats fed ad lib., for up to $48 \mathrm{~h}$, does not further increase HDC mRNA (Fig. 2). 


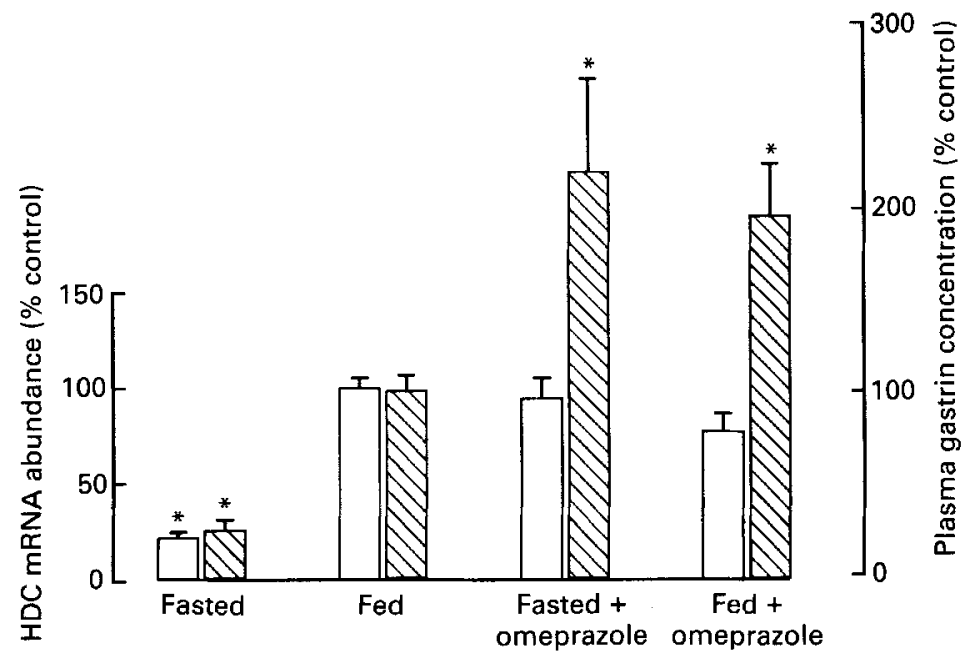

Fig. 2. Histidine decarboxylase (EC 4.1.1.22; HDC) mRNA levels and plasma gastrin concentrations in rat gastric corpus. Groups of six animals were fasted for $48 \mathrm{~h}$ or fed ad lib., and treated with vehicle ( $2 \mathrm{ml}$ methyl cellulose $(5 \mathrm{~g} / \mathrm{l}) / \mathrm{d})$ or omeprazole $(400 \mu \mathrm{mol} / \mathrm{kg}$ per d, orally). HDC mRNA abundance $(\square)$ was determined by Northern blot, and plasma gastrin concentrations $(\mathbb{\$})$ by radioimmunoassay (Dimaline et al. 1993b). Values are expressed as means with their standard errors, represented by vertical bars, for six animals. Mean values for treated animals were significantly different from those for animals fed ad lib. ( $t$ test): $* P<0 \cdot 05$.

This suggests that HDC mRNA is normally regulated over the physiological range of plasma gastrin concentrations. However, when fed rats are treated with omeprazole to maintain achlorhydria and hypergastrinaemia for up to 1 week, HDC mRNA increases several-fold above the levels seen in vehicle-treated controls (Swarovsky et al. 1994; Dimaline \& Struthers, 1995). If the hypergastrinaemia is chronic ( $>1$ year), rats develop ECL cell hyperplasia which progresses to dysplasia, and eventually leads to the formation of carcinoid tumours (Ekman et al. 1985; Poynter et al. 1985).

The decline in HDC mRNA abundance seen with fasting is progressive and gradual, but when animals that had been fasted for $48 \mathrm{~h}$ were refed HDC mRNA abundance was doubled within $30 \mathrm{~min}$ (Dimaline et al. 1993b, 1995). The rapid response to feeding was not seen in animals pre-treated with specific gastrin antagonists or with atropine (Baxendale et al. 1995; Dimaline et al. 1995), suggesting that both gastrinergic and muscarinic cholinergic mechanisms are important, and may act synergistically. This rapid increase in HDC mRNA could be mimicked by distension of the stomach for $30 \mathrm{~min}$ at a physiological pressure, and since nutritive and non-nutritive solutions were equally effective, it seems that passive mechanical distension is sufficient to account for the response (Dimaline et al. 1995). The rapidity of the response indicates the importance of newly synthesized HDC in meeting the demands for increased histamine production, and suggests that changes in HDC gene expression could regulate acid secretory function over the time taken to digest a single meal.

Chromogranin A. The chromogranin family of proteins (chromogranins A and B and secretogranin II) are widespread constituents of neuroendocrine cells, where they are often co-stored with peptides or amines. In the rat stomach, ECL cells appear to be the only source of chromogranin A (CGA) so that the protein provides a useful marker for this cell type (Fischer-Colbrie et al. 1987; Simon \& Aunis, 1989). CGA may be 
biosynthetically processed to give rise to a number of biologically active peptides, but in addition is believed to play a role in the stabilization and storage of secretory granules (Wiedenmann \& Huttner, 1989; Helle, 1990). In response to physiological challenges such as fasting and feeding, or pharmacologically-induced changes in gastric intralumen $\mathrm{pH}$, gastric corpus CGA mRNA abundance changed in the same direction as HDC mRNA, although the magnitude of change was smaller (Dimaline et al. 1993a). It seems likely that the changes in CGA mRNA expression are of functional significance, because under similar circumstances there were comparable changes in CGA-like immunoreactivity (Watkinson \& Dockray, 1992).

Amine transporters. Unlike secretory peptides and proteins, which enter the regulated pathway of secretion after ribosomal synthesis, amines such as histamine that are destined for secretion are synthesized in the cytoplasm and, therefore, must enter pre-formed secretory vesicles. Other biologically active monoamines such as the catecholamines and serotonin, are translocated across the secretory vesicle membrane by means of a vesicular monoamine transporter (VMAT), in exchange for intravesicular protons; the proton gradient is maintained by a vesicle resident V-type ATPase (Njus et al. 1986; Kanner \& Schuldiner, 1987; Johnson, 1988). Most of the early work to elucidate this pathway was performed on bovine adrenal chromaffin cells, but it seems likely that similar mechanisms exist in a wide range of cells that secrete monoamines. The cDNA encoding two VMAT have been characterized from rat; $\mathrm{VMAT}_{1}$ was cloned from PC12 cells and is expressed primarily in the adrenal, $\mathrm{VMAT}_{2}$ was cloned from brainstem and is expressed in central nervous system (Erickson et al. 1992; Liu et al.

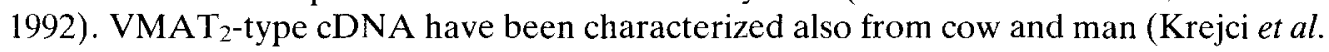
1993; Surratt et al. 1993; Howell et al. 1994).

By analogy with other monoamines, it seems plausible to suppose that histamine might be transported into the ECL cell secretory vesicle by a VMAT, although VMAT 1 and $\mathrm{VMAT}_{2}$ have affinities for histamine that are about 0.1 and $10 \%$ respectively of their affinities for other monoamines (Kirshner, 1962; Peter et al. 1994). Nevertheless, several lines of evidence suggest that $\mathrm{VMAT}_{2}$ may transport histamine into the ECL cell secretory granule. First, immunohistochemical studies have demonstrated the presence of $\mathrm{VMAT}_{2}$ in ECL cells (De Giorgio et al. 1994). Second, VMAT 2 cDNA has been cloned and sequenced from gastric corpus (Dimaline \& Struthers, 1995). Third, mRNA expression was demonstrated in enzymically-dispersed corpus mucosal cells that had been enriched with ECL cells (approximately 15\% ECL cells (Brenna \& Waldum, 1991)) by centrifugal elutriation (Dimaline \& Struthers, 1995). Finally, VMAT 2 mRNA abundance in gastric corpus was upregulated by achlorhydria, in parallel with HDC and CGA mRNA (Dimaline \& Struthers, 1995). The relatively low affinity for histamine shown by $\mathrm{VMAT}_{2}$ is apparently not a critical factor in the ECL cell. This cell type is essentially devoid of other amines (Hakanson, 1970; Rubin \& Schwartz, 1983, 1984), and the high levels of HDC presumably ensure that histamine is the only significant substrate for the transporter.

In response to hypergastrinaemia, secondary to achlorhydria it seems then that the ECL cell exhibits a coordinated response to upregulate expression of genes that are directly involved in histamine biosynthesis (Fig. 3). The increase in HDC mRNA is directly responsible for increased histamine synthesis, and the parallel rise in $\mathrm{VMAT}_{2}$ mRNA presumably reflects the increased requirement for transport into the secretory vesicle. There is good evidence for a V-type ATPase in the ECL cell granule membrane 


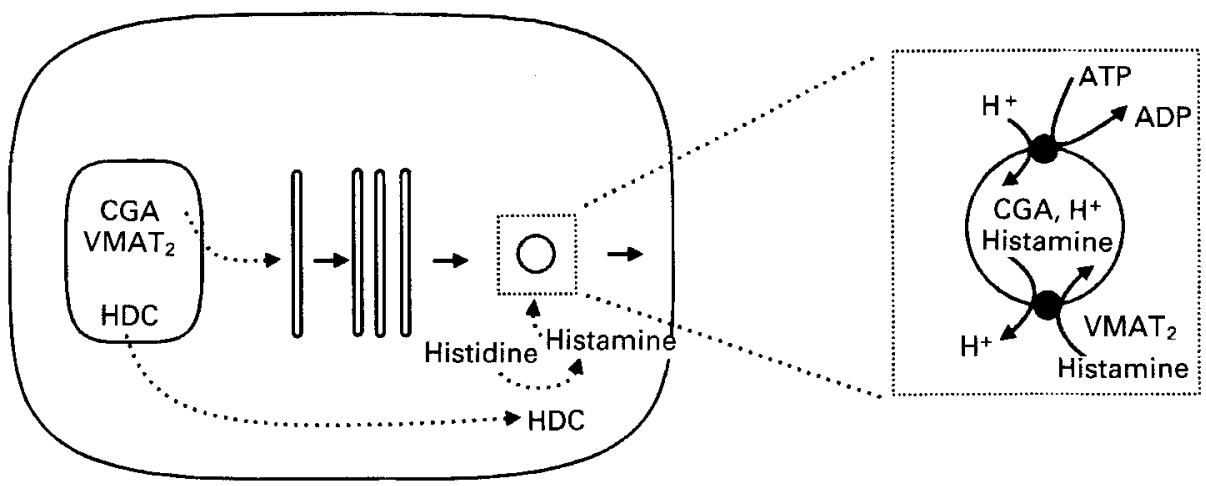

ECL cell

Secretory vesicle

Fig. 3. Schematic representation of histamine biosynthesis and sequestration into enterochromaffin-like (ECL) cell secretory vesicles. Histidine decarboxylase (EC 4.1.1.22; HDC) is located in the cytoplasm, where it converts histidine to histamine. Chromogranin A (CGA), vesicular monoamine transporter $\left(\mathrm{VMAT}_{2}\right)$ and a V-type ATPase enter the regulated pathway of secretion; CGA enters the secretory vesicle core, $\mathrm{VMAT}_{2}$ and the ATPase are inserted into the vesicle membrane. Histamine is translocated into the vesicle using the energy from the proton gradient. See text for further details.

(Prinz et al. 1993), but it remains to be determined if the increased demand on the proton gradient has consequences for the expression level of this enzyme. Increases in CGA and mRNA abundance suggest that this protein might be involved in stabilization of the ECL cell secretory vesicle. In addition, however, CGA and the products of its proteolytic processing will also be co-secreted with histamine, but the extracellular role that these molecules might play in the response to achlorhydria remains completely unexplored.

\section{LONG-TERM ADAPTIVE CHANGES IN GENE EXPRESSION}

The corpus D-cell

The role of the antral D-cell in mediating the inhibitory effects of gastric lumen acid is well established (see p. 267), but relatively little is known of the factors that regulate corpus $\mathrm{D}$-cell biosynthetic activity. The corpus $\mathrm{D}$-cell is of the closed type and, therefore, would not be expected to communicate directly with gastric lumen contents. Rats made achlorhydric for $48 \mathrm{~h}$ showed 3- or 4-fold decreases in antral somatostatin mRNA abundance, but corpus levels were virtually unchanged (Tari et al. 1991; Sandvik et al. 1993). Corpus D-cells were also relatively unaffected by food withdrawal, which at least doubled antral somatostatin mRNA abundance within $48 \mathrm{~h}$ (Wu et al. 1991; Sandvik et al. 1993). However, there is evidence that calcitonin-gene-related peptide (CGRP) is able to stimulate somatostatin secretion from the gastric corpus (Dunning \& Taborsky, 1987; Helton et al. 1989; Bunnett et al. 1990). This is of particular interest since in the rat CGRP is contained in over $80 \%$ of spinal gastric afferent neurones (compared with less than $10 \%$ of vagal afferents) while it is absent from gastric intrinsic neurons (Su et al. 1987; Green \& Dockray, 1988; Mulderry et al. 1988; Varro et al. 1988). Treatment of neonatal rats with the neurotoxin capsaicin, which selectively destroys small-diameter unmyelinated afferent neurons, abolishes gastric CGRP. Corpus somatostatin mRNA abundance was halved in capsaicin-treated rats, compared with vehicle-treated controls, 
and was also depressed in rats actively immunoneutralized against CGRP (Sandvik et al. 1993). Moreover, corpus somatostatin mRNA was elevated by CGRP infusion in conscious rats (Sandvik et al. 1993). It is well established that CGRP has important functions in gastric mucosal protection, including increasing mucosal blood flow and inhibiting gastric acid secretion (Holzer, 1994); it now seems that some of these actions might be mediated by stimulating corpus somatostatin biosynthesis.

However, in rats that have been pre-treated with capsaicin as neonates, and which have lost small-diameter primary afferents that contain CGRP (and substance P), basal and maximal levels of acid secretion are virtually unaffected, and the gastric mucosa appears macroscopically normal. It seems possible, therefore, that compensatory mechanisms might develop in capsaicin-treated rats that are able to alleviate the effects of losing the gastric afferent innervation. The action of substance $\mathrm{P}$ on antral somatostatin mRNA abundance is one possible example of such a mechanism. Thus, in capsaicin-treated, but not control rats, infusion of substance $P$ more than doubled antral somatostatin mRNA abundance (Fig. 4); it had no effect on corpus somatostatin mRNA in either capsaicin-treated or control rats (Dimaline et al. 1994). Apparently then, antral $D$-cells develop the capacity to respond to substance $P$ when the gastric primary afferent innervation is absent. Although substance $\mathrm{P}$ is present in about $50 \%$ of spinal gastric afferent neurones, it is also present in intrinsic neurones in the stomach that are spared by capsaicin, and it is this latter population that may develop a role in control of the antral D-cell in response to loss of the afferent neurons.
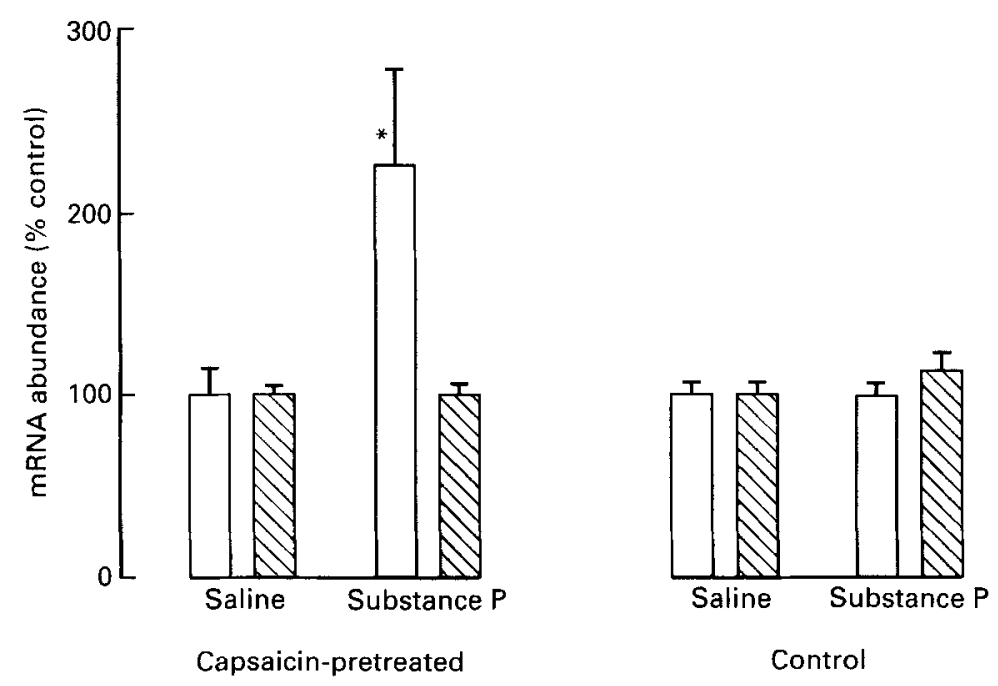

Fig. 4, Somatostatin $(\square)$ and glyceraldehyde-3-phosphate dehydrogenase (EC 1.2.1.12; GAPDH; $\mathbb{8}$ ) mRNA in gastric antrum of control and capsaicin-pretreated rats. Rats were treated as neonates with either capsaicin, to lesion small-diameter afferents (Sandvik et al. 1993), or saline $(9 \mathrm{~g} \mathrm{NaCl} / \mathrm{l}$ ). At $200-250 \mathrm{~g}$, groups of six animals were infused with substance $P(1 \mathrm{nmol} / \mathrm{kg}$ per $\mathrm{h})$ or saline for $6 \mathrm{~h}$. Somatostatin mRNA abundance in gastric antrum was determined by Northern blot; for comparison, abundance of mRNA encoding the non-regulated marker GAPDH was also estimated (Sandvik et al. 1993; Dimaline et al. 1994). Values are expressed as means with their standard errors, represented by vertical bars, for six animals. Mean values for capsaicin-treated animals were significantly different from those for saline-treated animals (one-way ANOVA): ${ }^{*} P<0 \cdot 05$. 


\section{THE SOMATOSTATIN RECEPTOR}

The coordinated pattern of response to somatostatin released from the gastrointestinal mucosa is determined partly by the location of the D-cells, since the peptide has a largely paracrine mode of action, and partly by the location of somatostatin receptors. In gastric antrum the G-cell is acknowledged as the major target for somatostatin, while in the corpus, targets include the ECL cell, the parietal cell and probably the oxyntic cell. Five distinct somatostatin receptors, designated SSTR1-5, have been cloned and sequenced (Bruno et al. 1992; Kluxen et al. 1992; Yamada et al. 1992a,b, 1993; Yasuda et al. 1992), that belong to the seven transmembrane domain G-protein coupling superfamily of receptors. Four of the five receptors show equal affinity for the two main biologically active forms of somatostatin (SOM 14 and SOM 28), while SSTR 5 is SOM 28 preferring.

In rat stomach, expression of four receptor types (SSTR1-4) has been reported, and there is evidence to suggest that SSTR2 mediates inhibition of acid secretion (Rossowski et al. 1994; Lloyd et al. 1995), and inhibition of histamine release from the ECL cell (Prinz et al. 1994). An mRNA splice variant of the SSTR2 subtype has been identified (designated SSTR2B) this is twenty-three amino acid residues shorter than the unspliced (SSTR2A) form; the two forms differ in their C-terminal fifteen amino acids (Vanetti et al. 1992; Patel et al. 1993). Messenger RNA encoding both SSTR2A (2.8 kb) and SSTR2B $(2.4 \mathrm{~kb})$ are expressed in rat gastric corpus, together with a third, smaller $1.6 \mathrm{~kb}$ variant. In enzymically-dispersed cells of gastric corpus mucosa, that were fractionated by centrifugal elutriation, the $1.6 \mathrm{~kb}$ form was present in the endocrine-cell-enriched fraction, but was only weakly expressed in parietal-cell-enriched fractions (Sandvik et al. 1995). In antrum, the $1.6 \mathrm{~kb}$ form was the predominant mRNA (Sandvik et al. 1995), and it is tempting to speculate that this may represent a somatostatin receptor specific to gastric endocrine cells. However, it remains to be established that this mRNA type encodes a functional receptor.

In both corpus and antrum, SSTR 2 mRNA abundance was altered by conditions such as changes in gastric lumen $\mathrm{pH}$, that also regulate somatostatin mRNA expression (Sandvik et al. 1995). For example, in rats treated with omeprazole for $48 \mathrm{~h}$, antral somatostatin mRNA abundance was reduced 3-fold; SSTR2 mRNA was modestly elevated (Sandvik et al. 1995), which may reflect an attempt to preserve the target cell response to diminishing concentrations of natural ligand. More surprisingly, SSTR2 mRNA abundance was increased by fasting, which also increased somatostatin mRNA (Sandvik et al. 1995). The physiological rationale for this latter observation is not yet clear, but it is consistent with the finding that, at least in an endocrine cell line $\left(\mathrm{GH}_{3}\right)$, exogenous somatostatin upregulates SSTR mRNA (Bruno et al. 1994).

Work in the author's laboratory is supported by the Medical Research Council and the Wellcome Trust.

\section{REFERENCES}

Baxendale, A. J., Dimaline, R. \& Spraggs, C. F. (1995). Gastrin/CCKB receptors mediate the feeding-induced increase in histidine decarboxylase (HDC) mRNA abundance in rat gastric corpus. Journal of Physiology 487, 71P Abstr.

Black, J. W., Duncan, W. A. M., Durant, C. J., Ganellin, C. R. \& Parsons, E. (1972). Definition and antagonism of histamine H2-receptors. Nature 236, 385-390. 
Black, J. W. \& Shankley, N. P. (1987). How does gastrin act to stimulate oxyntic cell secretion? Trends in Pharmacological Sciences 8, 486-490.

Brand, S. J. \& Stone, D. L. (1988). Reciprocal regulation of antral gastrin and somatostatin gene expression by omeprazole-induced achlorhydria. Journal of Clinical Investigation 82, 1059-1066.

Brenna, E. \& Waldum, H. L. (1991). Studies of isolated parietal and enterochromaffin-like cells from the rat. Scandinavian Journal of Gastroenterology 26, 1295-1306.

Bruno, J. F., Xu, Y. \& Berelowitz, M. (1994). Somatostatin regulates somatostatin receptor subtype mRNA expression in GH3 cells. Biochemical and Biophysical Research Communications 202, 1738-1743.

Bruno, J. F., Xu, Y., Song, J. \& Berelowitz, M. (1992). Molecular cloning and functional expression of a brain-specific somatostatin receptor. Proceedings of the National Academy of Sciences, USA 89, 1115111155 .

Bunnett, N. W., Helton, W. S., Debas, H. T. \& Ensinck, J. W. (1990). CGRP stimulates the release of pro-somatostatin-derived peptides from the gastric fundus. American Journal of Physiology 258, G316G319.

Chen, D., Monstein, H. J., Nylander, A. G., Zhao, C. M., Sundler, F. \& Hakanson, R. (1994). Acute responses of rat stomach enterochromaffinlike cells to gastrin: secretory activation and adaptation. Gastroenterology 107, 18-27.

Code, C. F. (1977). Reflections on histamine, gastric secretion and the $\mathrm{H}_{2}$ receptor. New England Journal of Medicine 25, 1459-1462.

De Giorgio, R., Su, D., Edwards, P. R. H., Brecha, N. C. \& Sternini, C. (1994). Monoamine vesicular transport and storage in the gut and pancreas. Digestive Diseases and Sciences 39, 1786 Abstr.

Dimaline, R., Evans, D. \& Dockray, G. J. (1995). Histidine decarboxylase mRNA in rat stomach is rapidly increased by distension, and by a postprandial cholinergic reflex. Gastroenterology 108, A963 Abstr.

Dimaline, R., Evans, D., Forster, E. R. \& Dockray, G. J. (1994). Stimulation of gastric somatostatin mRNA abundance by substance $P$ in capsaicin-treated rats. Neuroscience Letters $172,39-41$.

Dimaline, R., Evans, D., Forster, E. R., Sandvik, A. K. \& Dockray, G. J. (1993a). Control of gastric corpus chromogranin A messenger RNA abundance in the rat. American Journal of Physiology 264, G583-G588.

Dimaline, R., Evans, D., Varro, A. \& Dockray, G. J. (1991). Reversal by omeprazole of the depression of gastrin cell function by fasting in the rat. Journal of Physiology 433, 483-493.

Dimaline, R. \& Sandvik, A. K. (1991). Histidine decarboxylase gene expression in rat fundus is regulated by gastrin. FEBS Letters 281, 20-22.

Dimaline, R., Sandvik, A. K., Evans, D., Forster, E. R. \& Dockray, G. J. (1993b). Food stimulation of histidine decarboxylase messenger RNA abundance in rat gastric fundus. Journal of Physiology 465, 449-458.

Dimaline, R. \& Struthers, J. (1996). Expression and regulation of a vesicular monoamine transporter (VMAT2) in rat stomach: a putative histamine transporter. Journal of Physiology 490, 249-256.

Dockray, G. J., Hamer, C., Evans, D., Varro, A. \& Dimaline, R. (1991). The secretory kinetics of the G cell in omeprazole-treated rats. Gastroenterology 100, 1187-1194.

Dunning, B. E. \& Taborsky, G. J. Jr (1987). Calcitonin gene-related peptide: a potent and selective stimulator of gastrointestinal somatostatin secretion. Endocrinology 120, 1774-1781.

Edkins, J. S. (1905). On the chemical mechanism of gastric secretion. Proceedings of the Royal Society B 76, 376.

Ekman, L., Hansson, E., Havu, N., Carlsson, E. \& Lundberg, C. (1985). Toxicological studies on omeprazole. Scandinavian Journal of Gastroenterology 20, Suppl. 108, 53-69.

Erickson, J. D., Eiden, L. E. \& Hoffman, B. J. (1992). Expression cloning of a reserpine-sensitive vesicular monoamine transporter. Proceedings of the National Academy of Sciences, USA 89, 10993-10997.

Fischer-Colbrie, R., Hagne, C. \& Schober, M. (1987). Chromogranins A, B and C: widespread constituents of secretory vesicles. Annals of the New York Academy of Sciences 493, 120-134.

Green, T. \& Dockray, G. J. (1988). Characterization of the peptidergic afferent innervation of the stomach in the rat, mouse and guinea-pig. Neuroscience 25, 181-193.

Grossman, M. I. \& Konturek, S. J. (1974). Inhibition of acid secretion in dog by metiamide, a histamine antagonist acting on $\mathrm{H} 2$ receptors. Gastroenterology $66,517-521$.

Hakanson, R. (1970). New aspects of the formation and function of histamine, 5-hydroxytryptamine and dopamine in gastric mucosa. Acta Physiologica Scandinavica 340S, 1-134.

Hakanson, R., Kroesen, J. H., Liedberg, G., Oscarson, J., Rehfeld, J. F. \& Stadil, F. (1974). Correlation between serum gastrin concentration and rat stomach histidine decarboxylase activity. Journal of Physiology 243, 483-498. 
Helle, K. B. (1990). Chromogranins: universal proteins in secretory organelles from paramecium to man. Neurochemistry International 17, 165-175.

Helton, W. S., Mulholland, M. M., Bunnett, N. W. \& Debas, H. T. (1989). Inhibition of gastric and pancreatic secretion in dogs by CGRP: role of somatostatin. American Journal of Physiology 256, G715-G720.

Holzer, P. (1994). Calcitonin gene-related peptide. In Gut Peptides: Biochemistry and Physiology, pp. 493-523 [J. H. Walsh and G. J. Dockray, editors]. New York: Raven Press.

Howell, M., Shirvan, A., Stern-Bach, Y., Steiner-Mordoch, S., Strasser, J. E., Dean, G. E. \& Schuldiner, S. (1994). Cloning and functional expression of a tetrabenazine sensitive vesicular monoamine transporter from bovine chromaffin granules. FEBS Letters 338, 16-22.

Johnson, R. G. J. R. (1988). Accumulation of biological amines into chromaffin granules: a model for hormone and neurotransmitter transport. Physiological Reviews 68, 232-307.

Joseph, D. R., Sullivan, P. M., Wang, Y. M., Kozak, C., Fenstermacher, D. A., Behrendsen, M. E. \& Zahnow, C. A. (1990). Characterization and expression of the complementary DNA encoding rat histidine decarboxylase. Proceedings of the National Academy of Sciences, USA 87, 733-737.

Kahlson, G. \& Rosengren, E. (1971). Biogenesis and Physiology of Histamine. London: Edward Arnold Ltd.

Kanner, B. I. \& Schuldiner, S. (1987). Mechanism of transport and storage of neurotransmitters. CRC Critical Reviews in Biochemistry 22, 1-39.

Karnik, P. S., Monahan, S. J. \& Wolfe, M. M. (1989). Inhibition of gastrin gene expression by somatostatin. Journal of Clinical Investigation 83, 367-372.

Kirshner, N. (1962). Uptake of catecholamines by a particulate fraction of the adrenal medulla. Journal of Biological Chemistry 237, 2311-2317.

Kluxen, F. W., Bruns, C. \& Lubbert, H. (1992). Expression cloning of a rat brain somatostatin receptor cDNA. Proceedings of the National Academy of Sciences, USA 89, 4618-4622.

Krejci, E., Gasnier, B., Botton, D., Isambert, M.-F., Sagne, C., Gragnon, J., Massoulie, J. \& Henry, J.-P. (1993). Expression and regulation of the bovine vesicular monoamine transporter gene. FEBS Letters 335, 27-32.

Liu, Y., Peter, D., Roghani, A., Schuldiner, S., Prive, G. G., Eisenberg, D., Brecha, N. \& Edwards, P. R. H. (1992). A cDNA that suppresses MPP+ toxicity encodes a vesicular amine transporter. Cell 70, 539-551.

Lloyd, K. C. K., Wang, J., Aurang, K., Gronhed, P., Coy, D. H. \& Walsh, J. H. (1995). Activation of somatostatin receptor subtype 2 inhibits acid secretion in rats. American Journal of Physiology 268, G102-G106.

Moss, S., Legon, S. \& Calam, J. (1994). Reciprocal changes in antral gastrin and somatostatin mRNA in pernicious anemia. Digestive Diseases and Sciences 39, 321-326.

Mulderry, P. K., Ghatei, M. A., Spokes, R. A., Jones, P. M., Pierson, A. M., Hamid, Q. A., Kanse, S., Amara, S. G., Burrin, J. M., Legon, S., Polak, J. M.\& Bloom, S. R. (1988). Differential expression of $\alpha$-CGRP and $\beta$-CGRP by primary sensory neurons and enteric autonomic neurons of the rat. Neuroscience 25, 195-205.

Njus, D., Kelley, P. M. \& Hardanek, G. J. (1986). Bioenergetics of secretory vesicles. Biochimica et Biophysica Acta 853, 237-265.

Patel, Y. C., Greenwood, M., Kent, G., Panetta, R. \& Srikant, C. B. (1993). Multiple gene transcriptions of the somatostatin receptors SSTR2: tissue selective distribution and cAMP regulation. Biochemical and Biophysical Research Communications 192, 288-294.

Peter, D., Jimenez, J., Lius, Y., Kim, J. \& Edwards, P. R. H. (1994). The chromaffin granule and synaptic vesicle amine transporters differ in substrate recognition and sensitivity to inhibitors. Journal of Biological Chemistry 269, 7231-7237.

Popielski, L. (1920). $\beta$-Imidazolylathylamin und die Organextrakte. I, $\beta$-Imidazolylathylamin als machtiger Erreger der Magendrusen (Histamine and organ extracts. I, Histamine is as potent in stimulating the gastric glands). Pflugers Archiv 178, 214-236.

Poynter, D., Pick, C. R., Harcourt, R. A., Selway, S. A., Ainge, G., Harman, I. W., Spurling, N. W., Fluck, P. A. \& Cook, J. L. (1985). Association of long lasting unsurmountable histamine $\mathrm{H} 2$ blockade and gastric carcinoid tumours in the rat. Gut 26, 1284-1295.

Prinz, C., Kajimura, M., Scott, D. R., Mercier, F., Helander, H. F. \& Sachs, G. (1993). Histamine secretion from rat enterochromaffinlike cells. Gastroenterology $\mathbf{1 0 5}, 449-461$.

Prinz, C., Sachs, G., Walsh, J. H., Coy, D. H. \& Wu, S. V. (1994). The somatostatin receptor subtype on rat enterochromaffinlike cells. Gastroenterology 107, 1067-1074.

Rossowski, W. J., Gu, Z. F., Akarca, U. S., Jensen, R. T. \& Coy, D. H. (1994). Characterization of somatostatin receptor subtypes controlling rat gastric acid and pancreatic amylase release. Peptides $\mathbf{1 5}$, $1421-1424$. 
Rubin, W. \& Schwartz, B. (1983). Identification of the serotonin-synthesizing endocrine cells in the rat stomach by electronmicroscopic autoradiography and amine fluorescence. Gastroenterology 84, 34-50.

Rubin, W. \& Schwartz, B. (1984). Identification of the APUD endocrine cells of rat fundic mucosa by means of combined fluorescence and electron microscopy. Journal of Histochemistry and Cytochemistry 32, 67-75.

Ryberg, B., Tielemans, Y., Axelson, J., Carlsson, E., Hakanson, R., Mattsson, H., Sundler, F. \& Willems, G. (1990). Gastrin stimulates the self-replication rate of enterochromaffinlike cells in the rat stomach: effects of omeprazole, ranitidine and gastrin-17 in intact and antrectomized rats. Gastroenterology 99, 935-942.

Sandvik, A. K., Dimaline, R., Brenna, E. \& Waldum, H. L. (1995). Differential expression and regulation of somatostatin receptor subtype 2 (SSTR2) messenger RNA in rat gastric antrum and corpus. American Journal of Physiology 269, G542-G547.

Sandvik, A. K., Dimaline, R., Forster, E. R., Evans, D. \& Dockray, G. J. (1993). Differential control of somatostatin messenger RNA in rat gastric corpus and antrum: role of acid food and capsaicin-sensitive afferent neurons. Journal of Clinical Investigation 91, 244-250.

Sandvik, A. K., Kleveland, P. M. \& Waldum, H. L. (1988). Muscarinic M2 stimulation releases histamine in the totally isolated, vascularly perfused rat stomach. Scandinavian Journal of Gastroenterology 23, 1049-1056.

Sandvik, A. K., Waldum, H. L., Kleveland, P. M. \& Sognen, B. S. (1987). Gastrin produces an immediate and dose-dependent histamine release preceding acid secretion in the totally isolated, vascularly perfused rat stomach. Scandinavian Journal of Gastroenterology 22, 803-808.

Savany, A. \& Cronenberger, L. (1990). Relationship between the multiple forms of rat gastric histidine decarboxylase: effects of conditions favouring phosphorylation and dephosphorylation. Biochemistry International 20, 363-374.

Simon, J.-P. \& Aunis, D. (1989). Biochemistry of the chromogranin A protein family. Biochemical Journal 262, $1-13$.

Snyder, S. H. \& Epps, L. (1968). Regulation of histidine decarboxylase in rat stomach by gastrin: the effect of inhibitors of protein synthesis. Molecular Pharmacology 4, 187-195.

Soll, A. H., Amirian, D. A., Thomas, L. P., Reedy, T. J. \& Elashoff, J. D. (1984). Gastrin receptors on isolated canine parietal cells. Journal of Clinical Investigation 73, 1434-1447.

Su, H. C., Bishop, A. E., Power, R. F., Hamada, Y. \& Polak, J. M. (1987). Dual intrinsic and extrinsic origins of CGRP-and NPY-immunoreactive nerves of rat gut and pancreas. Journal of Neuroscience 7, 2674-2687.

Surratt, C. K., Persico, A. M., Yang, X.-D., Edgar, S. R. \& Bird, G. S. (1993). A human synaptic vesicle monoamine transporter cDNA predicts posttranslational modifications, reveals chromosome 10 localization and identifies Taq1 RFLP's. FEBS Letters 318, 325-330.

Swarovsky, B., Eissele, R., Gross, M., Kortner, G., Koop, H., Arnold, R. \& Simon, B. (1994). Expression of the gastric $\mathrm{H}^{+} / \mathrm{K}^{+}$-ATPase and histidine decarboxylase during omeprazole treatment. Digestion 55, 97-102.

Tari, A., Wu, S. V., Sumii, M., Sachs, G. \& Walsh, J. H. (1991). Regulation of rat gastric $\mathrm{H}^{+} / \mathrm{K}^{+}-\mathrm{A}^{\top} \mathrm{CPase}$ $\alpha$-subunit mRNA by omeprazole. Biochimica et Biophysica Acta 1129, 49-56.

Vanetti, M., Kouba, M., Wang, X. H., Vogt, G. \& Holt, V. (1992). Cloning and expression in a novel mouse somatostatin receptor (SSTR2B). FEBS Letters 311, 290-294.

Varro, A., Green, T., Holmes, S. \& Dockray, G. J. (1988). Calcitonin gene-related peptide in visceral afferent nerve fibres: quantification by radioimmunoassay and determination of axonal transport rates. Neuroscience 26, 927-932.

Watkinson, A. \& Dockray, G. J. (1992). Functional control of chromogranin A and B concentrations in the body of the rat stomach. Regulatory Peptides 40, 51-61.

Wiedenmann, B. \& Huttner, W. B. (1989). Synaptophysin and chromogranins/secretogranins - widespread constituents of distinct types of neuroendocrine vesicles, and new tool in tumour diagnosis. Virchows Archiv für Cell Pathologie 58, 95-121.

Wu, S. V., Giraud, A., Mogard, M., Sumii, K. \& Walsh, J. H. (1990). Effects of inhibition of gastric secretion on antral gastrin and somatostatin gene expression in rats. American Journal of Physiology 258, G788-G793.

Wu, S. V., Sumii, K., Tari, A., Sumii, M. \& Walsh, J. H. (1991). Regulation of rat antral gastrin and somatostatin gene expression during starvation and after feeding. Gastroenterology 101, 1552-1558.

Yamada, Y., Kagimoto, S., Kubota, A., Yasuda, K., Masuda, K., Someya, Y., Ihara, Y., Li, Q., Imura, H., Seino, S. \& Seino, Y. (1993). Cloning, functional expression and pharmacological characterization of a fourth (hSSTR4) and a fifth (hSSTR5) human somatostatin receptor subtype. Biochemical and Biophysical Research Communications 195, 844-852. 
Yamada, Y., Post, S. R., Wang, K., Tager, H. S., Bell, G. I. \& Seino, S. (1992a). Cloning and functional characterization of a family of human and mouse somatostatin receptors expressed in brain, gastrointestinal tract and kidney. Proceedings of the National Academy of Sciences, USA 89, 251-255.

Yamada, Y., Reisine, T., Law, S. F., Ihara, Y., Kubota, A., Kagimoto, S., Seino, M., Seino, Y., Bell, G. I. \& Seino, S. (1992b). Somatostatin receptors, an expanding gene family: cloning and functional characterization of human SSTR3, a protein coupled to adenylyl cyclase. Molecular Endocrinology 6, 2136-2142.

Yasuda, K., Rens, K., Domiano, S., Breder, C. D. \& Law, S. F. (1992). Cloning of a novel somatostatin receptor, SSTR3, coupled to adenylylcyclase. Journal of Biological Chemistry 267, 20422-20428. 